\title{
PENGARUH KEDISIPLINAN SISWA TERHADAP PRESTASI BELAJAR MATEMATIKA
}

\author{
UMAR WIRANTASA \\ wirantasaumar@gmail.com \\ 085695175271 \\ Program Studi Teknik Informatika, Fakultas Teknik, Matematika, dan IPA \\ Universitas Indraprasta PGRI
}

\begin{abstract}
Abstrak. Penelitian ini bertujuan untuk mengetahui pengaruh kedisiplinan siswa terhadap prestasi belajar matematika. Penelitian ini dilaksanakan di SMP Negeri 223 Jakarta yang beralamat di Jalan Surilang Kelurahan Gedong Kecamatan Pasar Rebo Jakarta Timur pada tanggal 5 Juni 2012. Metode yang dipakai yaitu metode survei dengan menggunakan instrumen angket sebanyak 30 item pernyataan yang terdiri dari bobot positif dan negatif. Jumlah sampel yang diambil dalam penelitian ini yaitu berjumlah 59 responden dari poulasi 235 siswa, yang diambil menggunakan teknik simple random sampling. Uji persyaratan analisis data yang dilakukan adalah uji normalitas menggunakan uji chikuadrat dan uji linearitas menggunakan uji $\mathrm{F}$ (Fisher), dan hasilnya data berdistribusi normal serta memenuhi uji linearitas yakni data bersifat linier/signifikan. Uji hipotesis yang dipakai yaitu uji validitas dengan menggunakan product moment dan uji reliabilitas data menggunakan Cronbach Alpha, jadi hasilnya layak dipakai/valid dan reliabel/layak dipakai, data yang valid yaitu 25 soal dan data yang tidak valid berjumlah 5 . Uji signifikan regresi yaitu menyatakan hipotesis Ho ditolak dan dapat disimpulkan terdapat hubungan yang signifikan antara kedisiplinan siswa terhadap prestasi belajar matematika. Dari hasil penelitian yang telah dilaksanakan dapat disimpulkan bahwa kedisiplinan siswa berpengaruh positif terhadap prestasi belajar matematika.
\end{abstract}

\section{Kata Kunci:Kedisiplinan Siswa, Prestasi Belajar Matematika}

\begin{abstract}
This study aims to determine the effect of Discipline of Students Against Learning Achievement in Mathematics. The research was conducted in SMP Negeri 223 Jakarta at Jalan Gedong Village Surilang Pasar Rebo Sub-district on June 5, 2012. The method used is a survey method using questionnaire instrument 30 items statements consisting of positive and negative weights. The number of samples taken in this study is numbered 59 respondents from Inroads 235 students, who were taken using simple random sampling technique. Test data analysis requirements are normality test using chisquare test and linearity test using the $\mathrm{F}$ test (Fisher), and the results were normal distribution of data while meeting the linearity test data is linear / significant. Hypothesis test used is a validity test by using product moment and reliability test data using Cronbach Alpha, so the results are utilizable / valid and reliable / feasible to use, valid data of 25 items and invalid data totaling 5. significant regression test that is stated Ho hypothesis is rejected and it can be concluded there is a significant relationship between the discipline of students towards mathematics achievement. From the research that has been done can be concluded that student discipline positive effect on mathematics achievement.
\end{abstract}

Keywords: Student Discipline, Learning Achievement in Mathematics 


\section{PENDAHULUAN}

Pendidikan pada dasarnya merupakan upaya dari manusia untuk dapat memperoleh pengetahuan dan keterampilan dalam rangka memenuhi kelangsungan hidupnya. Pendidikan merupakan salah satu kebutuhan pokok dalam kehidupan manusia yang memikirkan bagaimana menjalani kehidupan ini untuk mempertahankan hidup manusia yang mengemban tugas dari Sang Kholiq untuk beribadah. Berdasarkan Undangundang Sisdiknas No. 20 Tahun 2003 Bab I pasal 3, pendidikan adalah:

"Usaha sadar dan terencana untuk mewujudkan suasana belajar dan proses pembelajaran agar peserta didik secara aktif mengembangkan potensi dirinya untuk memiliki kekuatan spiritual keagamaan, pengendalian diri, kepribadian, kecerdasan, akhlak mulia, serta keterampilan yang diperlukan bagi dirinya, masyarakat, bangsa dan negara”.

Pendidikan harus dilihat dalam cakupan pengertian yang luas. Pendidikan bukan merupakan suatu proses yang netral sehingga terbebas begitu saja dari nilai-nilai dan ideologi. Pendidikan merupakan upaya terorganisir, berencana dan berlangsung kontinu (terus menerus sepanjang hayat) ke arah membina manusia/anak didik menjadi insan paripurna, dewasa dan berbudaya. Pendidikan merupakan upaya terorganisir yang memiliki makna bahwa pendidikan harus dilakukan oleh usaha sadar manusia dengan dasar dan tujuan jelas, ada tahapannya dan ada komitmen bersama didalam proses pendidikan.

Pendidikan di Indonesia masih rendah dibandingkan dengan negara-negara tetangga seperti Malaysia atau Singapura, padahal dulu Malaysia berguru ke Indonesia. Indonesia sebagaimana negara berkembang lainnya memiliki permasalahan pendidikan yang tidak sederhana. Permasalahan pendidikan yang dialami oleh Indonesia yaitu tentang mutu pendidikan tersebut. Mutu pendidikan yang dimaksud yaitu tentang prestasi belajar matematika. Prestasi yang didapat oleh siswa sebagai tolak ukur bagi siswa tersebut sejauh mana ia telah memahami materi pelajaran matematika yang didapatkannya.

Banyak diantara siswa yang tidak memahami tentang pentingnya matematika. Ketidakpahaman siswa disebabkan kurangnya renungan tentang fungsi matematika itu sendiri. Padahal kalau siswa mau sedikit merenung mengenai pentingan matematika maka banyak sekali fungsi matematika dalam kehidupan sehari-hari. Ketika siswa tersebut berangkat sekolah dengan menggunakan atau menaiki angkutan umum, maka ketika siswa turun dari angkutan tersebut ia akan membayar dengan sejumlah uang kepada supir angkutan tersebut. Kegiatan membayar uang tersebut adalah termasuk fungsi matematika. Selain itu dalam melaksanakan kegiatan sehari-hari kita tidak bisa jauh atau tanpa melihat sebuah waktu di jam. Kalau siswa mau mengamati jam tersebut maka terdapat angkaangka dari satu sampai dua belas, angka-angka tersebut juga termasuk fungsi matematika. Sebenarnya masih banyak sekali fungsi matematika. Oleh sebab itu matematika sangat penting dalam berbagai aspek kehidupan.

Namun pada kenyataannya dengan banyak fungsi atau pentingnya matematika dalam kehidupan, matematika masih dipandang sebelah mata oleh sebagian siswa. Metematika adalah mata pelajaran yang tekenal "sulit", bahkan menjadi momok bagi banyak anak. Pada sisi lain ternyata ada juga anak yang menganggap matematika itu menyenangkan bahkan menantang. Perbedaan persepsi ini selain dilihat sebagai sematamata karena perbedaan salera masing-masing manusia, mungkin juga terkait dengan pengalaman buruk atau pengalaman menarik anak tersebut saat berinteraksi dengan matematika. Matematika adalah bidang studi wajib yang akan dijumpai anak dari SD sampai mahasiswa, bahkan bisa jadi sampai pascasarjana. Kebanyakan dari kita setuju bahwa matematika (setidaknya ilmu hitung dasar) adalah penting, karena menyadari betapa pentingnya matematika, orang tua tentu ingin putra-putrinya pintar matematika. 
Ini menjadi dilema karena disatu sisi orang tua dan guru ingin anak pintar matematika. Pada sisi lain karena matematika terkenal "sulit", ada persepsi tidak mudah membuat anak menjadi pintar matematika. Akibatnya adalah anak dipaksa mengalami penggemblengan luar biasa untuk mengalahkan mata pelajaran yang dikenal sulit tersebut. Perlahan-pahan anak kemudian mulai tertekan. Semakin anak tertekan dia cenderung lebih sukar menyerap pelajaran. Semakin anak tidak paham, orang tua merasa anak harus belajar lebih keras lagi. Tekanan menjadi semakin besar. Anak semakin sulit menyerap pelajaran.

Ketika siswa sudah mulai tertekandan sulit menyerap pelajaran matematika, maka efeknya yaitu pada prestasi belajar matematika tersebut. Banyak faktor yang mempengaruhi prestasi belajar diantaranya faktor dari dalam diri siswa (intern) dan faktor dari luar diri siswa (ekstern). Karena banyak faktor yang mempengaruhinya, maka peneliti mengambil salah satu faktor yang mempengaruhi prestasi belajar matematika yaitu kedisiplinan siswa tersebut. Kita sadari bahwa yang namanya kedisiplinan sangat penting dalam segala aspek kegiatan apapun, baik kegiatan belajar, bekerja, olahraga dan sebagainya. Berbicara mengenai kedisiplinan sangat menarik karena banyak orang mengartikan bahwa kedisiplinan itu bagaikan dipenjara. Padahal sikap kedisiplinan itu sangat menarik, apabila tentunya kita mau berubah untuk disiplin dalam segala hal.

Kedisiplinan itu sangat penting untuk perkembangan siswa demi masa depan yang cerah. Karena dengan kedisiplinan,siswa akan termotivasi untuk mencapai apa yang siswa inginkan dancita-citakan. Disamping itu kedisiplinan juga sangat bermanfaat untuk mendidik siswa lebih menyukai peraturan-peraturan atau jadwal yang sudah siswa tetapkan sehingga dapat menghasilkan hasil yang memuaskan. Kedisiplinan merupakan suatu faktor yang harus ditanamkan, dikembangkan, serta dilaksanakan dalam kehidupan sehari-hari untuk mencapai suatu keberhasilan dalam segala hal, salah satunya keberhasilan dalam proses belajar, sebab belajar bukanlah usaha yang ringan atau boleh bermalas-malasan, malainkan suatu usaha yang besar, yang rajin, tekun dan terusmenerus (kontinu) yang semuanya membutuhkan kerja keras baik secara mental, pikiran, tenaga, mau memanfaatkan waktu luang dengan semaksimal mungkin untuk belajar.

Hampir disemua sekolah mengalami kesulitan dalam pembelajaran matematika termasuk pada siswa SMP Negeri 223 Jakarta. Dari hasil pengamatan atau pantauan sementara, terlihat adanya kedisiplinan siswa yang kurang. Buktinya hasil pengamatan peneliti masih banyak siswa disaat datang sekolah masih saja ada yang terlambat, selain itu masih diantara siswa yang kurang mentaati tata tertib yang ada dan disaat pergantian jam pelajaran masih saja di antara siswa yang mondar-mandir keluar kelas dengan alasan izin ketoilet dan sebagainya. Prestasi belajar matematika yang rendah dibandingan mata pelajaran yang lainnya. Buktinya masih saja sebagian siswa yang nilai untuk pelajaran matematika dibawah standar kelulusan atau ketuntasan belajar yang ditetapkan oleh sekolah tersebut yaitu 7,0.Selain kedisiplinan siswa yang kurang, motivasi juga mempengaruhi prestasi belajar matematika.

Berdasarkan uraian-uraian di atas, peneliti tertarik untuk meneliti lebih lanjut mengenai pentingnya kedisiplinan siswadan mengangkatnya dalam penelitian dengan judul "Pengaruh Kedisiplinan SiswaTerhadap Prestasi Belajar Matematika".

\section{TINJAUAN PUSTAKA \\ Hakikat Belajar}

Merumuskan definisi mengenai belajar yang memadai bukan suatu pekerjaan yang mudah. Hal ini disebabkan definisi tentang belajar banyak sekali. Hal ini disebabkan perbedaan sudut pandang dari setiap ahli. Namun tidak mengurangi arti dari belajar itu sendiri. Pengertian belajar juga dikemukakan oleh Slameto (2010:2) yakni "belajar adalah 
suatu proses usaha yang dilakukan seseorang untuk memperoleh suatu perubahan tingkah laku yang baru secara keseluruhan, sebagai hasil pengalamannya sendiri dalam interaksi dengan lingkungannya".Proses belajar adalah perubahan tingkah laku yang baru secara keseluruhan. Perubahan yang terjadi dalam proses belajar baik perubahan sikap maupun pengetahuan yang dimiliki. Proses belajar tidak hanya di dapat dari hasil membaca dan sebagainya, melainkan hasil dari pengalaman sendiri dalam interaksi dengan lingkungannya.

Menurut Asmani (2009:19) "belajar adalah proses mencari ilmu untuk mengubah diri dengan baik, sesuai dengan tingkat keilmuan yang dicapai". Dalam proses belajar yang paling utama adalah mencari ilmu. Dalam proses pencarian ilmu sesorang harus mau mengorbankan baik meteri dan material. Proses pencarian ilmu yang di dapat untuk mengubah diri dengan baik dan sesuai dengan tingkat keilmuan yang dicapai. Perubahan yang baik selain dari sisi keilmuan juga dari tingkat keilmuan yang dipelajari. Sedangkan menurut Suprayekti (2010:160) "belajar adalah kegiatan yang berproses dan merupakan unsur yang sangat fundamental dalam setiap penyelenggaraan jenis dan jenjang pendidikan termasuk pendidikan tinggi". Jenjang pendidikan sangat banyak dalam proses belajar. Jenjang pendidikan yang kita kenal dalam proses belajar meliputi jenjang pendidikan dasar atau yang kita kenal dengan sekolah dasar (SD). Selanjutnya jenjang pendidikan menengah pertama atau yang kita kenal dengan SMP dan sekolah menengah atas atau yang kita kenal dengan SMA/MA/SMK. Selain itu juga ada jenjang pendidikan tinggi yaitu yang kita kenal dengan perguruan tinggi. Peruguruan tinggi yang kita kenal terdiri dari perguruan tinggi negeri dan perguruan tinggi swasta.

Selaras dengan pendapat-pendapat di atas, menurut Aisyah dan Fatimah (2011:84) "belajar adalah suatu perubahan yang terjadi melalui latihan atau pengalaman". Pengalaman seseorang sangat berbeda antara orang satu dengan orang yang lainnya. Ada pengalaman yang baik dan ada pengalamannya yang kurang baik. Ketika seseorang mendapatkan sebuah pengalaman yang kurang baik maka seseorang tersebut cenderung memperbaikinya. Selain itu Menurut Herkusumo dan kawan-kawan (2009:17) "belajar adalah sebagai proses atau kegiatan yang membawa perubahan dalam arti perilaku aktual maupun potensial dipengaruhi oleh banyak faktor dan salah satu faktor penting adalah faktor lingkungan". Proses belajar terjadi dari sebuah proses pengisian jiwa berupa pengetahuan-pengetahuan yang di dapat dari beberapa sumber ilmu pengetahuan. Selain dari beberapa sumber untuk mendapatkan pengetahuan, pengalaman juga salah satu sumber pengetahuan dalam belajar. Setelah mendapatkan pengetahuan dari beberapa sumber dan hasil pengalaman yang banyak, dalam proses belajar seseorang akan menghafal bagian yang penting dari pengetahuan yang di dapat dan menyimpannya di dalam memori otak.

Sedangkan menurut Sriyono (2011:114) belajar yaitu: "proses aktivitas yang dilakukan secara sadar oleh manusia dengan memberdayakan panca indra yang dimilikinya untuk mendapatkan perubahan tingkah laku, kemampuan, keterampilan maupun sifat-sifat yang ada dalam dirinya kearah yang lebih baik sebagai hasil pengalaman dan interaksi dan lingkungan".

Belajar merupakan proses sadar manusia dengan memberdayakan beberapa panca indra. Dalam proses belajar seseorang tidak hanya menggunakan salah satu panca indra saja. Melainkan harus menggunakan panca indra lainnya. Dalam proses membaca saja misalnya, kita tidak hanya menggunakan mata untuk melihat huruf-huruf yang ada di dalam sebuah buku, tetapi harus ada kerjasama antara mulut, tangan dan otak. Selain memberdayakan panca indra yang kita miliki, hasil dari belajar adalah perubahan tingkah laku yang baik, bertambahnya pengetahuan yang dimiliki seseorang dari hasil pengalaman dan interaksi dengan lingkungan. 
Dari beberapa pendapat para ahli dapat disimpulkan bahwa belajar itu senantiasa merupakan perubahan tingkah laku atau penampilan, dengan serangkaian kegiatan misalnya dengan membaca, mengamati, mendengarkan, meniru dan lain sebagainya, perubahan tersebut berupa perubahan pengetahuan, pemahaman, keterampilan dan sikap yang bersifat menetap.

\section{Hakikat Prestasi Belajar}

Kemampuan intelektual siswa sangat menentukan keberhasilan siswa dalam memperoleh prestasi. Untuk mengetahui berhasil tidaknya seseorang dalam belajar maka perlu dilakukan suatu evaluasi, tujuannya untuk mengetahui prestasi yang diperoleh siswa setelah proses belajar mengajar berlangsung. Pengertian tentang prestasi telah banyak dikemukakan oleh banyak pakar pendidikan dan bisa dikatakan difinisi tersebut berbeda sebanyak mereka yang mengemukakannya. Menurut Nelsusmena (2010:151) "prestasi belajar adalah skor atau nilai yang diperoleh siswa dari hasil tes belajar yang menyatakan minimal 60\% penguasaan terhadap materi pelajaran". Tolak ukur tingkat keberhasilan prestasi belajar seseorang yaitu apabila hasil tes yang mereka lakukan menyatakan hasilnya minimal $60 \%$ penguasaan terhadap materi pelajaran. Penguasaan materi pelajaran yang baik akan menghasilkan hasil tes yang baik pula. Apabila hasil tes penguasaan materi menunjukkan nilainya di atas $60 \%$ dari penguasaan materi, maka dapat dikatakan seorang siswa berhasil. Dan apabila hasil tes penguasaan materi menunjukkan nilainya di bawah $60 \%$ dari penguasaan materi, maka dapat dikatakan seorang siswa belum berhasil.

Selain itu menurut Tarno (2010:28) "prestasi belajar adalah suatu hasil yang dicapai oleh masing-masing siswa dalam periode waktu tertentu sebagai hasil dari belajar biasanya berupa angka". Hasil dari sebuah prestasi siswa dilakukan pada periode tertentu. Pada proses kenaikan kelas maka hasil yang menentukan dari siswa tersebut berhak atau tidaknya naik ke kelas selanjutnya yaitu hasil dari ujian akhir sekolah (UAS). untuk menentukan tingkat keberhasilan siswa dalam belajar biasanya berupa angka. Sedangkan menurut Djaelani dan Mahfud (2007: 15) "prestasi belajar adalah penguasaan pengetahuan atau keterampilan yang dikembangkan oleh mata pelajaran, lazimnya ditunjukkan dengan nilai tes atau angka nilai yang diberikan oleh guru". Pengusaan siswa terhadap materi merupakan tolak ukur berhasil atau tidaknya siswa dalam proses belajar. Keberhasilan siswa ditandai dengan keterampilan yang dikembangkan oleh materi pelajaran yang telah ia dapatkan dalam proses belajar. Biasanya seorang guru memberikan nilai untuk mengukur tingkat keberhasilan yang dicapai oleh seorang siswa. Keberhasilan prestasi belajar sangat dipengaruhi oleh beberapa faktor-faktor, diantaranya faktor dari dalam diri siswa (intern) yaitu fakor jasmani, faktor psikologis dan faktor kelelahan. Selain itu faktor dari luar diri siswa (ekstern) juga sangat mempengaruhi keberhasilan prestasi belajar siswa, yaitu faktor keluarga, faktor sekolah dan faktor lingkungan masyarakat.

Definisi diatas dapat disimpulkan bahwa pengertian prestasi belajar ialah hasil usaha bekerja atau belajar yang menunjukkan ukuran kecakapan yang dicapai dalam bentuk nilai.

\section{Hakikat Matematika}

Memahami ilmu matematika sebagai salah satu upaya mengenal matematika merupakan hal penting. Sebab, pemahaman berkaitan dengan persepsi atau anggapan yang terbentuk. Jika persepsi terhadap matematika itu rumit, maka orang cenderung memahami matematika sebagai sesuatu yang sulit. Oleh karena itu, baik siswa, guru, maupun orang tua, harus memiliki pemahaman yang tepat terhadap ilmu eksak yang satu 
ini. Menurut Suhendri (2011:32) "bahwa matematika adalah ilmu tentang bilangan, bangun, hubungan-hubungan konsep dan logika dengan menggunakan bahasa lambang atau simbol dalam menyelesaikan masalah-masalah dalam kehidupan sehari-hari”. Matematika merupakan ilmu tentang bilangan-bilangan yang banyak menggunakan beberapa simbol. Dalam kehidupan sehari-hari hubungan konsep dan logika dengan menggunakan bahasa lambang atau simbol dapat menyelesaikan masalah kehidupan.Selain itu menurut Kadir (2005:233) "matematika adalah pelajaran tentang ide atau konsep serta hubungan yang ada di antara ide atau konsep tersebut". Konsep dan ide sangat diperlukan dalam metematika. Dalam matematika, terdapat suatu konsep yang penting, yaitu "fungsi", "variabel" dan konstanta". Konsep berhubungan erat dengan definisi, karena definisi adalah ungkapan suatu konsep. Dengan adanya definisi, orang dapat membuat ilustrasi, gambar, atau lambang dari konsep yang dimaksud.Menurut Siregar (2002:22) "bahwa matematika berkembang dari pikiran-pikiran manusia yang berhubungan dengan ide-ide, struktur-struktur dan konsep-konsep abstrak yang akhirnya dapat membantu dalam menginterprestasikan secara tepat berbagai ide dan kesimpulan". Matematika tidak berkembang dengan begitu saja. Metematika berkembang dari pikiranpikiran manusia yang berhubungan dengan ide, struktur dan konsep abstrak. Dari ide, struktur dan konsep tersebut akhirnya dapat membantu dalam menginterprestasikan secara tepat berbagai ide dan kesimpulan.

Berdasarkan pendapat-pendapat diatas, dapat disimpulkan bahwa matematika adalah ilmu yang mempelajari tentang bilangan, konsep-konsep dan struktur mencari hubungan-hubungan antara konsep-konsep dan struktur-struktur matematika itu dengan menggunakan lambang-lambang atau simbol-simbol, dalam mempelajarinya membutuhkan ketekunan dan ketelitian.

\section{Hakikat Prestasi Belajar Matematika}

Merumuskan definisi mengenai prestasi belajar matematika yang memadai bukan suatu pekerjaan yang mudah. Hal ini disebabkan definisi tentang prestasi belajar matematika banyak sekali. Hal ini disebabkan perbedaan sudut pandang dari setiap ahli. Namun tidak mengurangi arti dari prestasi belajar matematika itu sendiri.Menurut Tarno (2010:28)"prestasi belajar matematika adalah angka yang dicapai oleh masing-masing siswa setelah mengerjakan tes pada akhir periode pembelajaran standar kompetensi dan kompetensi dasar matematika yang telah dicapai". Tolak ukur dari sebuah prestasi belajar matematika adalah mengerjakan tes pada akhir periode pembelajaran standar kompetensi dan kompetensi dasar matematika yang dicapai. Keberhasilan prestasi belajar matematika biasanya di tandai oleh hasil yang berupa angka.Kemudian menurut Kadir (2005:233) "prestasi belajar matematika adalah merupakan salah satu ukuran tingkat keberhasilan siswa setelah menjalani proses belajar". Tingkat keberhasilan dalam prestasi belajar matematika ditandai oleh ukuran siswa setelah menjalani proses belajar. Proses belajar yang baik maka prestasi belajar matematikanya juga baik. Sebaliknya proses belajar yang kurang baik maka prestasi belajar matematikanya kurang baik pula.

Berdasarkan paparan teori di atas dapat diambil kesimpulan bahwa prestasi belajar matematika adalah tingkat penguasaan yang dicapai siswa dalam mengikuti proses belajar mengajar matematika sesuai dengan tujuan yang ditetapkan, prestasi yang dicapai oleh siswa merupakan gambaran hasil belajar siswa setelah mengikuti proses belajar mengajar dan merupakan interaksi antara beberapa faktor.

\section{Hakikat Kedisiplinan Siswa}

Kedisiplinan berasal dari kata dasar disiplin, menurut Roswita dalam John (2011:13) Disiplin berasal dari bahasa Inggris discipline yang berarti "training to act 
accordance with rules," melatih seseorang untuk bertindak sesuai aturan. Menurut Unaradjan (2003:10) "disiplin diri adalah tingkah laku manusia yang terkontol, terkendali, serta teratur yang berpijak pada kesadaran dan maksud luhur dari pribadi yang bersangkutan agar keberadaannya selalu membahagiakan dirinya dan orang lain".Disiplin merupakan tingkah laku yang terkontrol dan kendali. Terkontrol dan kendali yang dimaksud yaitu mampu mengontrol dan mengendalikan diri dari perbuatan yang melanggar aturan.Kemudian pendapat lain menurut Fatimah (2011:53) bahwa "disiplin adalah merupakan aspek dari proses sosialisasi yang mengarahkan individu untuk memenuhi/mentaati apa yang diharapkan lingkungannya (keluarga, sekolah dan masyarakat) daripadanya".Kedisiplinan merupakan aspek individu yang mengarahkan pada sikap untuk mentaati apa yang diharapkan lingkungannya, baik lingkungan keluarga, sekolah dan masyarakat. Dalam lingkungan keluarga kedisiplinan yang dimaksud yaitu dengan mentaati peraturan yang telah dibuat oleh keluarga. Dalam lingkungan sekolah kedisiplinan yang dimaksud yaitu dengan mentaati peraturan yang telah dibuat oleh sekolah. Sedangkandalam lingkungan masyarakat kedisiplinan yang dimaksud yaitu dengan mentaati peraturan yang telah dibuat oleh masyarakat.

Dari bebarapa teori yang dikemukakan oleh para ahli di atas maka dapat disimpulkan bahwa kedisiplinan adalah kesediaan untuk (taat, tunduk, nurut, patuh) pada aturan, norma-norma (baik norma agama maupun norma kesusilaan) baik yang tertulis maupun tidak tertulis, baik didalam lingkungan (keluarga, sekolah dan masyarakat), merupakan arahan untuk melatih dan membentuk seseorang untuk melakukan sesuatu menjadi lebih baik.

\section{METODE}

Penelitian ini merupakan penelitian survei. Menurut Kerlinger dalam Riduwan (2010:49) bahwa "penelitian survei adalah penelitian yang dilakukan pada populasi besar maupun kecil, tetapi data yang dipelajari adalah data dari sampel yang diambil dari populasi tersebut, sehingga ditemukan kejadian-kejadian relatif, distribusi dan hubungan antar variabel sosiologis maupun psikologis".

Munurut Sugiyono (2007:8) pola hubungan antara variabel yang akan diteliti tersebut selanjutnya disebut sebagai paradigma penelitian atau model penelitian/desain penelitian. Adapun desain penelitiannya adalah sebagai berikut:

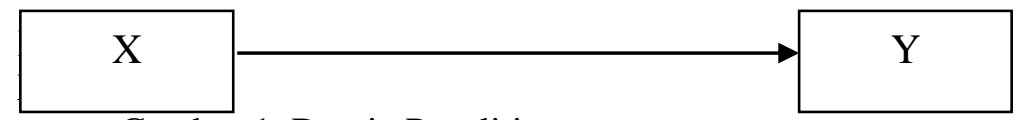

Gambar 1. Desain Penelitian

Keterangan:

$\mathrm{X}=$ Kedisiplinan Siswa

$\mathrm{Y}=$ Prestasi Belajar Matematika

Dalam penelitian ini yang menjadi populasi adalah:

1) Populasi target dalam penelitian ini adalah seluruh siswa dan siswi kelasSMP Negeri 223 Jakarta tahun pelajaran 2011/2012 yang berjumlah 678 Orang.

2) Populasi terjangkau adalah siswa dan siswi kelas VIIISMP Negeri 223 Jakarta Timur tahun pelajaran 2011/2012 yang berjumlah 235 orang dengan rincian sebagai berikut: 
Tabel 1. Jumlah siswa dan siswi kelas VIII SMP Negeri 223 Jakarta

\begin{tabular}{|c|c|c|c|c|}
\hline \multirow{2}{*}{ No } & \multirow{2}{*}{ Kelas } & \multicolumn{2}{|c|}{ Jumlah } & \multirow{2}{*}{ Jumlah } \\
\cline { 3 - 4 } & & Laki-laki & Perempuan & \\
\hline 1 & VIII-A & 22 & 16 & 38 \\
\hline 2 & VIII-B & 23 & 15 & 38 \\
\hline 3 & VIII-C & 26 & 13 & 39 \\
\hline 4 & VIII-D & 21 & 19 & 40 \\
\hline 5 & VIII-E & 15 & 25 & 40 \\
\hline 6 & VIII-F & 22 & 18 & 40 \\
\hline \multicolumn{2}{|c|}{ Jumlah Seluruhnya } & 129 & 106 & 235 \\
\hline
\end{tabular}

Menurut Supardi (2012:26) sampel adalah bagian dari populasi yang mempunyai ciri-ciri atau keadaan tertentu yang akan diteliti. Sampel dalam penelitian kuantitatif merupakan subjek penelitian yang dianggap mewakali populasi dan biasanya disebut responden penelitian. Menurut Arikunto (2002:120) mengemukakan bahwa "untuk sekedar perkiraan apabila subyek kurang dari 100, maka lebih baik diambil semua, sehingga penelitiannya merupakan penelitian populasi”. Selanjutnya jika subyeknya besar, dapat diambil antara $10 \%$ - $15 \%$ atau $20 \%$ - 25\% atau lebih.Adapun jumlah sampel dalam penelitian ini yaitu $25 \%$ dari 235 yaitu 59 orang.

Teknik pengambilan sampel dalam tugas ini adalah teknik simple random sampling. Menurut Riduwan (2010:58) simple random sampling adalah cara pengambilan sampel dan anggota populasi dengan menggunakan acak tanpa memperhatikan strata (tingkatan) dalam anggota populasi tersebut. Populasi targetnya pada penelitian ini adalah siswa kelas VIII Sekolah Menengah Pertama Negeri (SMP N) 223 Jakarta, yang terdaftar pada semester genap tahun pelajaran 2011-2012 dimana jumlah populasi adalah 235 siswa dan jumlah sampel adalah 59 siswa/siswi.

\section{HASIL DAN PEMBAHASAN}

Data Kedisiplinan Siswa

Dari hasil pengukuran dari 59 siswa didapat skor maksimum 123 dan skor minimum 83,sehingga didapat rentangan 40. Hasil analisis data diperoleh mean sebesar 104,72, median sebesar 105,19, modus 105,3, dan simpangan baku 8,76.

\section{Data Prestasi Belajar Matematika}

Dari hasil pengukuran dari 59 siswa didapat skor maksimum 92,50 dan skor minimum 40,00,sehingga didapat rentangan 52,50. Hasil analisis data diperoleh mean sebesar 66,96, median sebesar 68, modus 75,77, dan simpangan baku 12,33.

\section{Pengujian Persyaratan Analisis \\ Uji Normalitas}

Untuk menguji apakah data dari variabel-variabel yang diteliti bersifat normal digunakan uji Chi Kuadrat. Hipotesa yang digunakan adalah sebagai berikut:

Ho:Berdistribusi normal

$\mathrm{H}_{1}$ :Tidak berdistribusi normal

Terima Ho bila Chi Kuadrat Hitung < Chi Kuadrat Tabel dan

tolak Ho bila Chi Kuadrat Hitung > Chi Kuadrat Tabel

Dengan menggunakan program Microsoft Exceldiperoleh hasil perhitungan sebagai berikut: 
Tabel 2.Hasil Perhitungan Normalitas

\begin{tabular}{|c|c|c|c|}
\hline Variabel & $\begin{array}{l}\text { Chi Kuadrat } \\
\text { Hitung }\end{array}$ & $\begin{array}{l}\text { Chi Kuadrat } \\
\text { Tabel }\end{array}$ & Kesimpulan \\
\hline Kedisiplinan Siswa & 2,84 & \multirow{2}{*}{12,592} & Distribusi Normal \\
\hline $\begin{array}{l}\text { Prestasi Belajar } \\
\text { Matematika }\end{array}$ & 10,39 & & Distribusi Normal \\
\hline
\end{tabular}

Maka dapat disimpulkan secara keseluruhan bahwa data untuk setiap variabel berdistribusi normal, sehingga analisis selanjutnya akan dihitung menggunakan analisis statistik parametrik.

\section{Uji Linieritas}

Uji linieritas dilakukan untuk menguji apakah bentuk persamaan yang dihasilkan linier atau tidak. Pengujian dilakukan dengan menggunakan Tabel Ringkasan ANAVA, dengan hipotesa sebagai berikut:

Ho =Persamaan regresi tidak linier

$\mathrm{H}_{1}=$ Persamaan regresi linier

Dengan kriteria pengujian:

Terima Ho jika $\mathrm{F}_{\text {hitung }}>\mathrm{F}_{\text {tabel }}$

Tolak Ho jika $F_{\text {hitung }}<F_{\text {tabel }}$

Setelah dilakukan perhitungan di Microsoft Excel (pada lampiran 5) diperoleh hasil sebagai berikut:

Tabel 3. Ringkasan ANAVA Hasil Uji Linieritas

\begin{tabular}{|c|c|c|c|c|c|}
\hline $\begin{array}{l}\text { Sumber } \\
\text { Varians }\end{array}$ & $\mathbf{d k}$ & JK & RJK & $\mathbf{F}_{\text {hitung }}$ & $\mathbf{F}_{\text {tabel }}$ \\
\hline Total & 59 & $267.600,00$ & - & \multirow{6}{*}{$-1,106$} & \multirow{6}{*}{1,865} \\
\hline Reg (a) & 1 & $259.120,3$ & $259.120,3$ & & \\
\hline $\operatorname{Reg}(\mathbf{b} \mid \mathbf{a})$ & 1 & $6.480,2$ & $6.480,2$ & & \\
\hline Residu & 57 & $1.999,5$ & 35,1 & & \\
\hline Tuna Cocok & 27 & $-435.870,0$ & $-16.585,1$ & & \\
\hline Error & 30 & 437.869,5 & $14.993,2$ & & \\
\hline
\end{tabular}

Karena $F_{\text {hitung }}(-1,106)<\mathrm{F}_{\text {tabel }}(1,865)$ sehingga dapat disimpulkan bahwa persamaan regresi yang dihasilkan memenuhi pola linier.

\section{Pengujian Hipotesis Penelitian}

Langkah selanjutnya adalah menganalisis data yang masuk, untuk mengetahui apakah terdapat pengaruh antara variabel $\mathrm{X}$ (kedisiplinan siswa) terhadap variabel $\mathrm{Y}$ (prestasi belajar matematika), dengan menggunakan uji koefisien korelasi, uji koefisien determinasi, uji signifikansi korelasi,uji persamaan regresi, uji signifikan regresi.

\section{Uji Koefisien Korelasi} hipotesis.

Setelah semua persyaratan terpenuhi, maka selanjutnya dapat dilakukan uji Interpretasi nilai r menurut Sugiyono (2007: 231): 
Tabel 4. Interpretasi Koefisien Korelasi

\begin{tabular}{|l|l|}
\hline Nilai $r$ & Interpretasi \\
\hline $0,80-1,00$ & Sangat Kuat \\
$0,60-0,799$ & Kuat \\
$0,40-0,599$ & Sedang \\
$0,20-0,399$ & Lemah \\
$0,00-0,199$ & Sangat Lemah \\
\hline
\end{tabular}

$$
\begin{aligned}
r & =\frac{n \sum x \cdot y-\sum x \cdot \sum y}{\sqrt{n \sum x^{2}-\left(\sum x\right)^{2}} \sqrt{n \sum y^{2}-\left(\sum y\right)^{2}}} \\
r & =\frac{59 \times 414093-6167 \times 3910}{\sqrt{59 \times 649105-(6167)^{2} \times 59267600-(3910)^{2}}} \\
r & =0,8742
\end{aligned}
$$

Dari nilai korelasi di atas dapat disimpulkan bahwa ada korelasi positif yang sangat kuat antara kedisiplinan siswadengan prestasi belajar matematika.

\section{Uji Koefisien Determinasi}

Perhitungan koefisien determinasi:

$$
\begin{aligned}
& \mathrm{KD}=\mathrm{r}^{2} \times 100 \% \\
& \mathrm{KD}=(0,8742)^{2} \times 100 \% \\
& \mathrm{KD}=76,42 \%
\end{aligned}
$$

Ini dapat diartikan bahwa kedisiplinan siswa memberikan kontribusi sebesar76,42\% terhadap peningkatan prestasi belajar matematika.

\section{Uji Signifikansi Korelasi}

Setelah nilai koefisien korelasi diketahui langkah selanjutnya adalah dilakukan pengujian signifikansi korelasi menggunakan uji-t, perhitungannya sebagai berikut:

$$
\begin{aligned}
& t_{\text {hitung }}=\frac{r \sqrt{n-2}}{\sqrt{1-\mathrm{r}^{2}}} \\
t_{\text {hitung }}= & \frac{0,8742 \sqrt{59-2}}{\sqrt{1-(0,8742)^{2}}} \\
t_{\text {hitung }}= & 13,59
\end{aligned}
$$

Berdasarkan perhitungan pengujian signifikansi korelasi diperoleh hasil $t_{\text {hitung }}=13,59$ dan pada $(n-2)=(59-2)=57$, taraf signifikan 0,05 diperoleh $t_{\text {tabel }}=1,676$. Karena $t_{\text {hitung }}>t_{\text {tabel }}$ maka Ho ditolak, yang berarti terdapat korelasipositif yang signifikan antara kedisiplinan siswa dengan prestasi belajar matematika.

\section{Uji Persamaan Regresi}

Langkah selanjutnya menghitung persamaan regresi, yaitu: $\hat{Y}=a+b x$. Dengan menggunakan program Microsoft Excel diperoleh hasil perhitungansebagai berikut:

$$
\begin{array}{lll}
\sum x=6167 & \sum x^{2}=649105 & \sum x y=414092,5 \\
\sum y=3.910,00 \quad \sum y^{2}=267.600,00 & n=59 \\
a=\frac{\sum Y \cdot \sum X^{2}-\sum X \cdot \sum X Y}{n \cdot \sum X^{2}-(X)^{2}} & \\
=\frac{3910,00 x 649105-6167 x 414092,5}{59 x 649105-38031889} & \\
=\frac{2538000550-2553708447,5}{38297195-38031889} &
\end{array}
$$




$$
\begin{aligned}
& =\frac{-15707897,5}{265306} \\
& =-59,2067179031 \\
& =-59,21
\end{aligned}
$$

Koefisien arah regresi yaitu:

$$
\begin{aligned}
& b=\frac{n \cdot \sum X Y-\sum X \cdot \sum Y}{n \cdot \sum X^{2}-\left(\sum X\right)^{2}} \\
& =\frac{59 \times 414092,5-6167 \times 3910,00}{59 \times 649105-38031889} \\
& =\frac{24431457,5-24112970}{38297195-38031889} \\
& =\frac{318487,5}{265306} \\
& =1,2004534386708 \\
& =1,20
\end{aligned}
$$

Sehingga diperoleh persamaan garis regresi $\widehat{Y}=-59,1+1,20 \mathrm{X}$ yang berarti setiap penambahan satu kedisiplinan siswaterjadi penambahan prestasi belajar matematika sebesar 1,20 .

\section{Uji Signifikan Regresi}

Selanjutnya dilakukan pengujian signifikansi regresi dengan rumus F (Fisher) sebagai berikut:

$$
\begin{aligned}
F_{\text {hitung }} & =\frac{\mathrm{RJK}_{\mathrm{reg}(\mathrm{b} \mid \mathrm{a})}}{\mathrm{RJK}_{\mathrm{res}}} \\
\mathrm{F}_{\text {hitung }} & =\frac{6480,16}{35,1} \\
\mathrm{~F}_{\text {hitung }} & =184,731
\end{aligned}
$$

Berdasarkan perhitungan pengujian signifikansi korelasi diperoleh hasil $\mathrm{F}_{\text {hitung }}=184,731$ dan $d k$ pembilang $=1$, dan $d k$ penyebut $=59-2=57$, taraf signifikan 0,05 diperoleh $F$ tabel $=4,01$. Ini berarti $F_{\text {hitung }}>F_{\text {tabel }}(184,731>4,01)$ yang menyatakan hipotesis $\mathrm{H}_{0}$ di tolak dan dapat disimpulkan terdapat pengaruh yang signifikan kedisiplinan siswa $(\mathrm{X})$ terhadap prestasi belajar matematika.

\section{Pembahasan}

Berdasarkan penelitian yang telah dilakukan terhadap siswa di kelas VIII SMP N 223 Jakarta dengan jumlah sampel sebanyak 59 orang, ingin mengetahui hubungan antara kedisiplinan siswa dengan prestasi belajar matematika SMP Negeri 223 Jakarta.

Berdasarkan data yang diperoleh dan hasil analisa data serta pengujian hipotesis, Kedisiplinan siswa termasuk dalam kategori sedang, karena berdasarkan perhitungan dan pengolahan data diperoleh dengan nilai rata-rata sebesar 104,72; nilai median sebesar 105,19; modus sebesar 105,30 dan simpangan baku sebesar 8,76. Sehingga dapat disimpulkan bahwa kedisiplinan siswa di SMP N 223 Jakarta tergolong sedang.

Prestasi belajar matematika siswa termasuk dalam kategori sedang, karena berdasarkan perhitungan dan pengolahan data diperoleh nilai rata-rata sebesar 66,96; nilai median sebesar 68,00; modus sebesar 75,77 dan simpangan baku sebesar 12,33. Sehingga disimpulkan bahwa prestasi belajar matematika di SMP N 223 Jakarta tergolong sedang. Koefisien korelasi antara kedisiplinan siswa dengan prestasi belajar matematika sebesar 0,8742 . Angka ini termasuk dalam kategori korelasi yang sangat kuat, sehingga dapat diartikan bahwa terdapat hubungan positif yang sangat kuat antara kedisiplinan siswa dengan prestasi belajar matematika, dimana nilai koefisien determinasi sebesar 76,42\%. Yang artinya variabel kedisiplinan siswa memberikan kontribusi sebesar 76,42\% terhadap prestasi belajar matematika. 
Nilai koefisien korelasi yang sangat kuat tersebut tidak jauh berbeda seperti pada penelitian Bayu Setioningsih (2010) yang berjudul Pengaruh Kedisiplinan Belajar Siswa Terhadap Prestasi Belajar Matematika. Hasil penelitian menunjukkan bahwa nilai koefisien korelasi antara kedisiplinan belajar siswa terhadap prestasi belajar matematika sebesar 0,97 dengan nilai kontribusi sebesar 94\%.

Hubungan yang signifikan antara kedisiplinan siswa dengan prestasi belajar matematika sebesar 13,59. Angka ini cukup kuat karena dapat diartikan sebagai hubungan yang kuat ditambah lagi dengan kontribusi yang diberikan oleh variabel kedisiplinan siswa terhadap prestasi belajar matematika sebesar $76,42 \%$. Yang artinya $76,42 \%$ prestasi belajar matematika siswa dipengaruhi oleh kedisiplinan siswa, sedangkan sisanya $23,58 \%$ dipengaruhi oleh faktor lain yang tidak dibahas dalam penelitian ini.

\section{PENUTUP}

\section{Simpulan}

Berdasarkan data penelitian dan hasil analisis data, maka peneliti dapat menyimpulkan bahwa terdapat pengaruh kedisiplian siswa terhadap prestasi belajar matematika. Artinya semakin tinggi kedisiplinan siswa maka semakin tinggi prestasi belajar siswa begitu pula sebaliknya. kedisiplinan siswa sangat mendukung dalam mencapai prestasi belajar khususnya pelajaran matematika, dalam mempelajari matematika diperlukankedisiplinan yang tinggi agar mendapatkan prestasi sesuai yang diharapkan.

\section{Saran}

Dengan memperhatikan hasil penelitian ini yang menyatakan bahwa terdapat hubungan yang kuat antara kedisiplinan siswa dengan prestasi belajar matematika, maka penulis memberikan saran-saran:

1. Siswa sebagai individu harus berusaha merubah kedisiplinan yang buruk dengan kedisiplinan yang baik, sehingga dalam menghadapi tantangan dan kesulitan dalam proses pembelajaran khususnya serta dunia masyarakat pada umumnya dapat lebih siap.

2. Guru harus lebih mengetahui faktor internal dan faktor eksternal yang berada dalam diri siswa agar guru dapat mengetahui perkembangan kedisiplinan siswa selama dalam proses kegiatan belajar mengajar.

3. Seluruh elemen pendidikan, siswa, orangtua, guru dan pemerintah harus mengupayakan kedisiplinan siswa yang tinggi, agar siswa belajar dalam kondisi yang aman, nyaman dan menyenangkan.

4. Siswa dan guru harus mampu mengembangkan suatu sistem pendidikan yang kondusif dimana siswa terpacu meningkatkan kompetensi dirinya yang pada akhirnya mampu membangkitkan kedisiplinan siswa yang baik, guna tercapainya prestasi belajar matematika yang memuaskan dan tercapainya segala cita-cita yang diinginkan.

\section{DAFTAR PUSTAKA}

Arifana, Muhammad. 2008. Kiat Menangkal Pelanggaran Ketertiban Sekolah. Pendidikan Network: Maju Tak Gentar Membela Yang Benar.

Arikunto, Suharsimi. 2002. Prosedur Penelitian. Jakarta: PT Rineka Cipta.

Asmani, Jamal Ma'mur. 2009. Jurus-jurus Belajar Efektif Untuk SMP dan SMA. Jogjakarta:DIVA Press.

Dwi, Prasti. 2011. (http://id.shvoong.com/social-sciences/education/2114599-upayameningkatkan-disiplin-belajar/). Tanggal akses 09 Mei 2012, 9:52:20. 
.(http://id.shvoong.com/social-sciences/psychology/2114582-unsur-unsurdisiplin). Tanggal akses 09 Mei 2012, 9:52:20.

Herkusumu, Arniati Prasedyawati dkk. 2009. Hubungan Antara Pengaturan Diri Dalam Belajar, Selt Efficacy, Lingkungan Belajar Di Rumah, Dan Itelegensi Dengan Prestasi Belajar. Jurnal Keberbakatan dan Kreativitas Vol. 03. No. 01, Februari. Fakultas Psikologi Universitas Indonesia.

John, Eltin. 2011. Upaya Meningkatkan Kedisiplinan Anak Di Kelas Melalui Cerita. Jurnal Pendidikan Penabur No. 16/ tahun ke-10 Juni.

Kadir. 2005. Pengaruh Pendekatan Problem Posing Terhadap Prestasi Belajar Matematika Jenjang Pengetahuan, Pemahaman, Aplikasi dan Evaluasi Ditinjau dari Metakognisi. Jurnal Pendidikan dan Kebudayaan, No. 053, Tahun Ke-11, Maret.

Nulsusmena. 2010. Hubungan Motivasi Berprestasi Dengan Prestasi Belajar Sejarah. Jurnal Educatio Indonesia Tahun 18, No. 2, Desember. FKIP Uhamka.

Riduwan. 2010. Belajar Mudah Penelitian Untuk Guru-Karyawan dan Peneliti Pemula. Bandung:CV Alfabeta.

Setioningsih, Bayu. 2010. Pengaruh Kedisiplinan Belajar Siswa Terhadap Prestasi Belajar Matematika (survey pada siswa kelas VII SMP Negeri 34 Bekasi).Skripsi. Jakarta: FT MIPA Universitas Indraprasta PGRI.

Siregar, Nurmaida Irawani. 2002. Pengaruh Pelatihan Sempoa (ABAKUS) Terhadap Prestasi Belajar Matematika. Tesis: Program Studi Pendidikan Minat Utama Psikologi Pendidikan Jurusan Ilmu-ilmu Sosial. Program Pasca Sarjana UGM Yogyakarta.

Slameto. 2010. Belajar dan Faktor-faktor yang Mempengaruhinya. Jakarta:PT Rineka Cipta.

Sriyono, Heru. 2011. Program Bimbingan Untuk Membantu Meningkatkan Kemandirian Belajar Siswa. Jurnal SOSIO e-KONS. Vol. III No.2 Mei-Juli. Jakarta: Universitas Indraprasta PGRI.

Sugiyono. 2007. Statistika untuk Penelitian. Bandung:CV Alfabeta.

Suhendri, Huri. 2011. Pengaruh Kecerdasan Matematis-Logis Dan Kemandirian Belajar Terhadap Hasil Belajar Matematika. Jurnal Formatif 1(1): 29-39 ISSN: 2088-351X. Jakarta: Program Studi Pendidikan Matematika FTMIPA Universitas Indraprasta PGRI.

Supardi. 2012. Aplikasi Statistika Dalam Penelitian: Buku Statistika Yang Paling Komprehensif. Jakarta: PT. Ufuk Publishing House.

Suprayekti. 2010. Keterampilan Belajar Mahasiswa. Jurnal Perspektif Ilmu Pendidikan. Vol. 22 Th. XIII Oktober. Jakarta:Fakultas Ilmu Pendidikan Negeri Jakarta.

Tarno. 2010. Peningkatan Prestasi Belajar Matematika Melalui Pembelajaran Kontektual. Jurnal Ilmiah Guru "COPE”, Nomor 02/Tahun XIV/November. Unarajan dan, Dolet. 2003. Manajemen Disiplin. Jakarta: PT. Grasindo. 